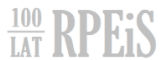

\section{UWARUNKOWANIA KONSENSUALNEGO MODELU DIALOGU SPOLECZNEGO I DIALOGU OBYWATELSKIEGO NA POZIOMIE REGIONALNYM W POLSCE}

\section{WSTĘP}

Konsensualizm to jedna z tych kategorii, po które chętnie sięga się w analitycznej narracji systemowo-politycznej oraz w porównawczych badaniach polityk publicznych ${ }^{1}$. Znakomita większość obywateli bez szczególnego wahania będzie skłonna wskazać na konsensus, odpowiadając na pytanie o to, czy w polityce publicznej bardziej należy cenić rywalizację czy uzgodnienia. Jest to stwierdzenie generalne, wynikające tyleż z potocznego przeczucia co naukowych uogólnień. W szczególności tych, które przekonuja, że ludzie - gdy tylko sa gotowi przełamywać sprzyjajacy postawom autorytarnym dogmatyzm w myśleniu - skłaniają się ku temu, co empatyczne i kooperacyjne w spoiwach swych charakterów, który to element występuje w psychice większości ludzi ${ }^{2}$. Choć warto także pamiętać, że nie zawsze - zwłaszcza w czasach niespokojnych, niepewnych, kryzysowych, a także nie u wszystkich, o czym przekonuje codzienność, ale i opracowania psychologów i psychiatrów ${ }^{3}$. Nie sposób też nie zauważyć, że w różnych zakątkach świata, w poszczególnych narodach, społeczeństwach, społecznościach i wspólnotach, na poziomach krajowych, regionalnych i lokalnych, częściej jednak do głosu dochodzą te elementy społecznego usposobienia człowieka, które są odpowiedzialne za rywalizację - spolaryzowaną emocjonalnie i nieuznającą konsensusu, nawet do tego stopnia, że

\footnotetext{
* Joanna Podgórska-Rykała, Uniwersytet Pedagogiczny w Krakowie, joanna.podgorska-rykala@up.krakow.pl, https://orcid.org/0000-0002-5723-0363.

** Jacek Sroka, Uniwersytet Pedagogiczny w Krakowie, jacek.sroka@up.krakow.pl, https://orcid.org/0000-0002-4432-3720.

1 Zob. Dahl (2000); Lijphart (2012).

2 Eysenck (1954); Rokeach (1960); Tomkins (1963).

3 Zob. Althemeyer (1996); Baron-Cohen (2015).
} 
każda próba jego ustalenia może być postrzegana jako niebezpieczna skłonność do zgniłego kompromisu i - jako taka - być piętnowana i usuwana poza nawias możliwych rozwiązań.

W sposób naturalny nasuwa się pytanie o to, dlaczego ludzie, mimo że wysoko cenią dialog i uzgodnieniowość, to w konkretnych uwarunkowaniach sytuacyjnych sięgają po strategie nieuzgodnieniowe i asymetryczne. Można przyjaćć, że - o ile generalnie jesteśmy skłonni do dialogowego poszukiwania tego, co nas łączy, o tyle jednocześnie w praktyce nierzadko przytłacza nas poczucie dialogowej niemocy - gdy górę biorą spolaryzowane interesy, emocje i subiektywne opinie. Są one wzmacniane dominującymi, niekonsensualnymi matrycami kulturowymi, które podpowiadają nam, że w danej sytuacji bezpieczniejsze, skuteczniejsze oraz szybsze od dialogowego poszukiwania konsensusu będzie postawienie spraw na ostrzu noża. W ten sposób ujawnia się w codzienności to, co w teorii bywa opatrywane takimi określeniami, jak m.in.: dylemat więźnia (prisoner's dilemma), jazda na gapę (free-riding) czy zależność od ścieżki rozwojowej (path dependency) ${ }^{4}$. O korzeniach tego problemu mówi między innymi ${ }^{5}$ twierdzenie Kennetha Arrowa, którego wydźwięk sprowadza się do tego, że znając podstawowy kurs historii oraz przytomnie obserwując rzeczywistość polityczna, dojdziemy do paradoksu, jeśli założymy, że: (a) gdy członkowie danej zbiorowości indywidualnie przejawiaja jednomyślność w wyborze pomiędzy dwoma alternatywami, to niechybnie znajdzie to także odzwierciedlenie na poziomie zagregowanym - jako preferencja społeczna i polityczna, która wykluczy możliwość istnienia dyktatury. Ta zaś sprowadza się do sytuacji, w której (b) pojawi się taka osoba, której preferencja będzie jednak (np. za sprawa kalkulacji rywalizacyjnych) odmienna od jednomyślnej preferencji obywateli i ostatecznie pociagnie za sobą niezgodne z nią rozstrzygnięcie publiczne ${ }^{6}$. Z drugiej strony wiadomo, że nawet w najbardziej spolaryzowanych oraz skłóconych społecznościach i społeczeństwach, gdzie preferencje są biegunowo odmienne, możliwy jest odwrót od patowej sytuacji, a droga ta wiedzie przez sprzyjające budowaniu konsensusu praktyki dialogowe ${ }^{7}$.

W artykule poszukuje się odpowiedniego dla polskich realiów konsensualnego modelu podobieństw, różnic, transferów praktyk oraz użyczania sieci współpracy $\mathrm{w}$ dialogu regionalnym. Poszukiwania te czynione są w ramach analizy dwóch zinstytucjonalizowanych odmian dialogu społecznego i obywatelskiego na poziomie województwa.

Dialog społeczny bywa utożsamiany z dialogiem obywatelskim, co stanowi błąd nie tylko z uwagi na oddzielne ustawowe regulacje obu dialogów w Polsce $^{8}$. W wymiarze instytucjonalnym dialog społeczny stanowi wyraz partner-

${ }^{4}$ Zob. Olson (1971), (1982); David (2000); Pierson (2000).

${ }^{5}$ Twierdzenia o podobnej wymowie formułowali m.in.: Black (1948); Sen (1978); Gibbard (1973); McKelvey (1976).

${ }^{6}$ Por. Arrow (1951).

${ }^{7}$ Zob. Maia et al. (2017); Owen, Smith (2015); Steiner, Jaramillo, Mameli (2017).

8 Ustawy: z 24 lipca 2015 r. o Radzie Dialogu Społecznego i innych instytucjach dialogu społecznego, Dz. U. 2018, poz. 2232 (dalej jako: u.RDS); z 24 kwietnia 2003 r. o działalności pożytku publicznego i o wolontariacie, Dz. U. 2019, poz. 688 (dalej jako: u.d.p.p.w.). 
stwa społecznego, którego historia jest spleciona ze stosunkami przemysłowymi. Nazwa tych relacji pochodzi stąd, że ich burzliwy rozwój, datujacy się od początków rewolucji przemysłowej, naznaczony był wieloma dramatycznymi wydarzeniami i przebiegał w sposób wielonurtowy. Tradycyjnym już mianem dialogu społecznego opatruje się dwustronne relacje pomiędzy partnerami społecznymi, tj. pracodawcami (organizacjami pracodawców i przedsiębiorców) a pracownikami (związkami zawodowymi, radami pracowników itp.) oraz władzami publicznymi. Przedmiotem tych relacji są - w węższym kontekście - zagadnienia i problemy związane ze stosunkami przemysłowymi ${ }^{9}$ (tj. z praca, zatrudnieniem, sprawami socjalnymi), a w kontekście szerszym, trójstronnym - z problematyką budżetu państwa, kierunkami rozwoju polityki społecznej i polityki gospodarczej, działaniami antykryzysowymi itd. Trójstronny dialog społeczny funkcjonuje w bardziej scentralizowanych formach europejskich stosunków przemysłowych, m.in. w Polsce, gdzie - oprócz tego, że wymienia się go w Konstytucji - przybiera konkretna, zinstytucjonalizowaną postać ogólnokrajowa - w postaci Rady Dialogu Społecznego (RDS) oraz regionalna, odzwierciedloną w Wojewódzkich Radach Dialogu Społecznego (WRDS).

Dialog obywatelski niekiedy nazywa się „młodszym bratem” dialogu społecznego ${ }^{10}$. Od ponad stulecia dialog obywatelski rozwija się bowiem w cieniu dialogu społecznego i w porównaniu ze swym starszym bratem bywa traktowany bardziej po macoszemu. Oprócz uwidaczniającej się w niektórych krajach słabości samego społeczeństwa obywatelskiego, dzieje się tak między innymi dlatego, że oddziaływania partnerów obywatelskich (głównie w postaci organizacji trzeciego sektora) cechuje znacznie mniejsza siła w porównaniu z możliwościami partnerów społecznych.

Partnerzy obywatelscy i ich organizacje są dużo bardziej zróżnicowani tak jak zróżnicowane są lokalne wspólnoty społeczne oraz jak zróżnicowany jest sam sektor organizacji pozarządowych. Wśród licznych form dialogu obywatelskiego można wymienić: wysłuchania publiczne, sądy i warsztaty obywatelskie, obywatelskie komórki planujące, konferencje uzgodnieniowe, panele obywatelskie, rady konsultacyjne i doradcze (np. młodzieżowe, seniorów, rady ds. rynku pracy, rady ds. osób niepełnosprawnych), a także budżetowanie partycypacyjne oraz wiele innych, do których stale dołączaja nowe rozwiązania i modyfikacje. Z uwagi na potrzebę utrzymania zwięzłej analizy skupiamy się tu na przykładzie rad działalności pożytku publicznego, które działaja w Polsce na podstawie regulacji ustawowej ${ }^{11}$. Sa one powoływane w jednostkach samorządu terytorialnego na wniosek co najmniej pięciu organizacji pozarządowych prowadzących działalność pożytku publicznego na danym terenie. Rady te zajmują się zagadnieniami odnoszącymi się do działalności pożytku publicznego oraz jej podmiotów (m.in.: opiniowaniem uchwał i aktów prawa miejscowego dotyczących zadań związanych z realizacja po-

\footnotetext{
9 Zob. np. Sroka (2000).

${ }_{10}$ Cisek-Lachowicz, Kichewko (2018): 59.

11 U.d.p.p.w.
} 
żytku publicznego; opiniowaniem funkcjonowania konkretnych organizacji pożytku publicznego; opiniowaniem projektów lokalnych strategii rozwojowych). Zgłaszają także propozycje priorytetów istotnych w działalności pożytku publicznego oraz opiniuja zlecanie zadań publicznych organizacjom pozarządowym. Udzielają również pomocy w przypadkach pojawienia się sporów pomiędzy organami administracji a organizacjami pozarządowymi.

Nasze rozważania prowadzone będa, mając na uwadze dobro, jakim jest publiczna deliberacja. Za teoretykami i praktykami uznajemy deliberację za jedna z tych dialogowych ścieżek (przed)decyzyjnych, które prowadzą ku trafnym rozstrzygnięciom i umożliwiają optymalne, sprawiedliwe, a zarazem przejrzyste publiczne zarządzanie zasobami środowiskowymi ${ }^{12}$. Wychodzimy z założenia, że w dialogowym kształtowaniu procesów publicznych liczy się nie tylko zależność od ścieżki rozwojowej, a więc od tego, co było, ale także kształtowanie tego, co będzie, przez wzajemne uczenie się nowych sposobów działania, umożliwiających korygowanie utrwalonych elementów niedialogowych przeszłości.

Mając na uwadze wyniki naszych wcześniejszych badań ${ }^{13}$, hipotetycznie zakładamy, że - w myśl koncepcji tzw. uczących się regionów ${ }^{14}$ - od jednego regionu inne województwa są w stanie uczyć się dialogu. Stąd też wynika decyzja, co do wyboru metody, jaką jest analiza porównawcza dialogu społecznego i dialogu obywatelskiego $\mathrm{w}$ polskich regionach $\mathrm{z}$ wykorzystaniem analizy prawnej oraz z zapożyczeniami ze studiów przypadków przeprowadzonych we wcześniejszych badaniach. Rezultatem tej analizy jest zawarta w artykule propozycja modelowego ujęcia deliberacyjnych relacji na poziomie regionalnym, na którego trzy główne elementy składają się: (1) dialogowe (deliberatywne) momenty, (2) dialogowe (deliberatywne) postawy, (3) siła słabych więzi. Propozycja ta wydaje się funkcjonalna dla zdiagnozowania stanu realnego w trakcie dalszych empirycznych badań terenowych - również wykraczających poza podstawową dyscyplinę naukową autorów niniejszego tekstu.

Wzajemnej dialogowej edukacji sprzyjać będzie także uczenie się od siebie w obszarze jednego regionu przez wzajemne czerpanie z doświadczeń dwóch wojewódzkich wariantów zinstytucjonalizowanego dialogu - społecznego i obywatelskiego. Obie te formy zinstytucjonalizowanego partnerstwa realizowane są w przestrzeni dwóch konkretnych ciał kolegialnych: Wojewódzkiej Rady Dialogu Społecznego (WRDS) oraz Wojewódzkiej Rady Działalności Pożytku Publicznego (WRDPP) ${ }^{15}$.

Warto zatem zastanawiać się nad tym, czy WRDS i WRDPP wymieniaja się zasobami oraz doświadczeniem, a co za tym idzie - czy mogą uczyć się od siebie deliberacji. Zakładamy, że jest to możliwe, co też stanowi główny powód zawartych w artykule poszukiwań modelowych. Wywiedzione uogólnienia składają się na tytułowy konsensualny model podobieństw, różnic, transferów

\footnotetext{
${ }^{12}$ Dryzek (2002); Parkinson, Mansbridge (2012); Sroka (2009); Zabdyr-Jamróz (2019).

${ }^{13}$ Sroka, Herbut, Sula (2004); Sroka, Błaszczyk (2006); Sroka (2008).

${ }^{14}$ Florida (1995): 532.

${ }^{15}$ Zob. przyp. 8.
} 
praktyk oraz użyczania sieci współpracy w regionalnym dialogu społecznym i obywatelskim. Model ten może stanowić analityczną ramę przyszłych badań empirycznych. Wątki poruszane w artykule odnoszą się do warstwy funkcjonalno-systemowej, co jest charakterystyczne dla badań sytuujących się w dyscyplinie nauk o polityce i administracji, ze szczególnym uwzględnieniem badań nad polityką publiczna, a częściowo także w dyscyplinie nauk prawnych i w studiach regionalnych oraz lokalnych.

Elementy modelowej odpowiedzi na podejmowane przez autorów kwestie konstruuje się w odniesieniu do regionu małopolskiego, który wytypowano, mając w pamięci rezultaty prowadzonych wcześniej przez jednego z nich badań ogólnokrajowych, z których wynikało, iż region ten posiada wyraźny potencjał sprzyjajacy rozwojowi instytucji dialogowych. Województwo małopolskie zostało wytypowane do porównawczej analizy obu regionalnych rad z uwagi na wyróżniająca je spośród pozostałych regionów aktywność w zakresie efektywnego wykorzystywania istniejących możliwości i powoływania licznych oraz stosunkowo sprawnych gremiów dialogowych. Obecnie (tj. jesienią 2020), przy Urzędzie Marszałkowskim funkcjonuje ich jedenaście, w tym dwie, które z uwagi na swoją specyfikę stanowią przedmiot analizy. W świetle dotąd zebranych danych można żywić nadzieję, że na małopolskich forach dialogowych z wolna utrwalają się interakcje stosunkowo najbliższe teoretycznym postulatom oraz praktycznym wymiarom deliberacji, a tym samym dobrym praktykom znanym z tych demokracji skonsolidowanych, w których przeważa konsensualna stylizacja procesów publicznych. Pogląd ten formułuje się tu, mając w pamięci ogólnopolskie badania porównawcze stanu regionalnego dialogu społecznego, w których uczestniczył jeden z autorów niniejszego tekstu (w latach 2003-2004 $4^{16}, 2005-2006^{17}$ oraz 2008-2009 ${ }^{18}$ ), oraz ogólnopolskie badania porównawcze wybranych centralnych, regionalnych oraz lokalnych instytucji dialogowych, które przeprowadzono w latach 2007-2009 ${ }^{19}$. Rezultaty były publikowane, upowszechniane na konferencjach oraz spotkaniach z partnerami społecznymi i obywatelskimi, także na forach dialogowych komisji. Były one dyskutowane, cytowane i - jak dotą - nie zostały naukowo podważone. W opinii piszących w sposób wystarczajacy uzasadnia to formułowane w tym tekście uogólnienie odnoszące się do województwa małopolskiego jako wyróżniającego się na tle kraju in plus regionalno-dialogowego przypadku.

W artykule omówiono dialogową specyfikę Małopolski, odwołując się do wcześniej prowadzonych badań własnych oraz wyników badań innych autorów, a także przedstawiono koncepcję dwuelementowego modelu. Na pierwszy z elementów modelu składają się, znane z najnowszej dyskusji naukowej: deliberatywne momenty (deliberative moments ${ }^{20}$ ) i deliberatywne postawy (deliberative stance ${ }^{21}$ ), o których dalej. Element ten został skomentowany w odnie-

\footnotetext{
16 Sroka, Herbut, Sula (2004).

17 Sroka, Błaszczyk (2006).

18 Sroka (2009).

19 Sroka (2008).

20 Maia et al. (2017); Steiner, Jaramillo, Mameli (2017).

${ }^{21}$ Chambers (1996); Owen, Smith (2015); Zabdyr-Jamróz (2019): 39-41 i 60-65.
} 
sieniu do poziomu regionalnego w Polsce - w szczególności w odniesieniu do potencjału oddziaływania elitaryzmu na rozwój regionalnych środowisk sieciowych (policy networks ${ }^{22}$ ). Dalej wprowadzone zostały propozycje drugiego modelowego elementu, którego istota sprowadza się do znanego naukom społecznym pojęcia siły słabych więzi. Został on skomentowany w nawiązaniu do polskiego poziomu regionalnego z propozycja analizy zakresu oddziaływania w regionie ośmiu (autorsko przeredagowanych) zasad zarządzania środowiskami wspólnotowymi, które sformułowała Elinor Ostrom ${ }^{23}$. Wskazano też na możliwe warianty realnych wcieleń oraz deformacji proponowanych założeń modelowych, które moga pojawić się w regionach, a także na systemowe znaczenie modelu, wraz z detalami odnoszącymi się do dwóch cytowanych już ustaw regulujacych regionalny dialog społeczny i obywatelski. W artykule nie definiuje się wszystkich ważnych pojęć (m.in. układów sieciowych - policy networks), nie tylko dlatego, że są one charakteryzowane w literaturze krajowej (także w tekstach naszego autorstwa) i zagranicznej, ale przede wszystkim z uwagi na twarde wydawnicze ograniczenia edycyjne, których wymaganiom staraliśmy się sprostać.

\section{DELIBERATYWNE MOMENTY I DELIBERATYWNE POSTAWY JAKO SKŁADNIKI DELIBERACJI}

Jane J. Mansbridge wskazuje, że: system deliberatywny (deliberative system $^{24}$ ) ma współcześnie bardzo szeroki, holistyczny zakres i w różnym zakresie obejmuje szereg wymiarów nieformalnych, życiowych i sformalizowanych, systemowych ${ }^{25}$. Tak rozumiany system deliberatywny obejmuje jednostki i grupy, sieci i instytucje, szeroką opinię publiczna, ale także - wcale nie mniej ważne - minipubliki, znane choćby z codziennych, tzw. rozmów w maglu, w trakcie których oprócz kwestii prywatnych poruszane są także różne aspekty lokalnych spraw publicznych. Zatem w ujęciu substancjalnym system deliberatywny to całokształt rozmów - formalnych i nieformalnych, prowadzonych na różnych arenach, w rozmaitych minipublikach, w różnych gremiach oraz na zróżnicowanych forach, zarówno rozmów publicznych (w szkole, urzędzie czy w biurze), jak i rozmów niepublicznych, prowadzonych w kuchni (every day talk). Te „kuchenne rozmowy”, czy - bliżej polskiej frazeologii - „rozmowy w maglu", Mansbridge uznaje za ważny element oddolnego kształtowania się osądu publicznego. Istotnym składnikiem kształtowania się tego osądu jest, zidentyfikowana już w 1973 r. przez Marka Granovettera, tzw. siła słabych więzi (strenght of weak ties ${ }^{26}$ ), tj. siła więzi nawiązywanych lokalnie, ale poza kręgiem krewnych i przyjaciół (relatives). Istotnym, ale nie wyłącznym wkła-

\footnotetext{
22 Rhodes (2008).

${ }^{23}$ Hess, Ostrom (2001).

24 Zob. Parkinson, Mansbridge (2012).

25 Por. Mansbridge, Flaster (2007).

${ }^{26}$ Por. Granovetter (1973).
} 
dem wymiarem tych relacji jest taka wymiana korzyści, która nie szkodzi dobru publicznemu ${ }^{27}$.

Deliberatywne postawy i deliberatywne momenty są zarówno postulowane przez badaczy, jak i - w zależności od lokalnych uwarunkowań, mniej lub bardziej samorzutnie - praktykowane w mini-, mezo- oraz makropublikach. Praktykowane są wszędzie tam, gdzie stawia się na pomostowe (bridging ${ }^{28}$ ) sieciowanie, partycypację w podejmowaniu decyzji publicznych oraz przezwyciężanie polaryzacji afektywnej ${ }^{29}$. Wszędzie tam, gdzie preferuje się żmudne, ale skuteczne budowanie klimatu uogólnionego zaufania oraz konsensualne i otwarte ukierunkowywanie procesów intermediacji interesów jednostkowych, grupowych oraz publicznych (interest intermediation ${ }^{30}$ ). Mówiąc o otwartym ukierunkowaniu intermediacji interesów, ma się tu na myśli sytuację, w której wykluczane są opresywne oddziaływania z tych obszarów o charakterze publiczno-prywatnym, gdzie dominują ukryte struktury kooperacji i wymiany oraz kontrolujace je grupy interesu ${ }^{31}$. Dotychczasowe doświadczenia i wyniki badań skłaniają do wniosku, że nie są one w małopolskich radach widoczne, co jednak nie oznacza, że nie istniejac. Wątek ten warto poddawać dalszej weryfikacji.

\section{POTENCJALNE ODDZIALYWANIE ELITARYZMU NA ROZWÓJ ŚRODOWISK SIECIOWYCH (POLICY NETWORKS): PRZYPADEK MAŁOPOLSKI}

Organizacja małopolskich gremiów dialogowych, przebieg obrad z udziałem interesariuszy oraz ich rezultaty już od lat przekonuja, że w przypadku tego województwa mamy do czynienia wprawdzie nie ze spektakularnym rozwojem dialogu - takiego bowiem nie obserwuje się nigdzie w kraju, ale z widocznym jego wzmacnianiem. Nie jest to więc jeszcze, tak pożądany, splot deliberatywnych momentów i deliberatywnych postaw, ale też nie jest to jedynie przelotne ożywienie prodialogowych orientacji, aktywności oraz mechanizmów sprawczych.

W trakcie wcześniej prowadzonych badań w Małopolsce ${ }^{32}$, na tle innych regionów, zwracał uwage między innymi uroczysty elitarny klimat dialogowych interakcji, który - gdyby uległ nadmiernemu wzmocnieniu - prawdopodobnie będzie przeszkadzał, a nie pomagał rozwojowi deliberacji. Zarazem jednak wspomniany klimat może stanowić rezultat lokalnie stylizowanych

27 Mansbridge et al. (2010).

${ }^{28}$ Popularne już dziś rozróżnienie sieciowych powiązań włączających, inkluzywnych (bridging) oraz powiązań spajających, ekskluzywnych (bonding) - w skrajnych przypadkach o „bastionowym” charakterze - wprowadzili do literatury naukowej Ross Gittell i Avis Vidal (1998).

${ }^{29}$ Zob. Sroka, Podgórska-Rykała (2020a), (2020b); Podgórska-Rykała (2020).

30 Por. Lehner (1987).

31 Zob. Sroka, Podgórska-Rykała (2020c).

32 Sroka, Herbut, Sula (2004); Sroka, Błaszczyk (2006); Sroka (2008), (2009). 
profesjonalnych postaw uczestników dialogu, których forma z jakiegoś powodu nakazywała im przyjmowanie uroczystej pozy oraz dystyngowanego tonu. Możliwe zatem, że wspomniane „poza” oraz „ton” nie są wyrazem skłonności do budowania relacji asymetrycznych, co dialogowi z pewnością by nie służyło, lecz stanowią wyraz galicyjskiego kolorytu kulturowego. O tym, czy zidentyfikowanie tego elitarnego klimatu dialogowych interakcji nie było jedynie złudzeniem, oraz ewentualnie, czy - jeśli rzeczywiście występuje klimat ten stanowi element galicyjskiej kultury relacji publicznych, powinny przekonać ewentualne badania empiryczne. W badaniach przeszłych znacznie silniej od wspomnianej uroczystej sztywności zaznaczały się pozytywne wymiary interakcji. W tym przede wszystkim: kompleksowość, wielowymiarowość oraz zdrowe wytonowanie dyskusji nad zgłaszanymi pod obrady problemami. Profesjonalizm małopolskiego dialogu nie był, rzecz jasna, wyłącznie efektem stylizacji postaw, gdyż ta ostatecznie zawsze stanowi ucieleśnienie dominujących lokalnie rysów kulturowych. Wynikał on głównie z bardzo dobrego przygotowywania agendy spotkań, z rzetelnego przygotowania materiałów odnoszących się do dyskutowanych spraw, a także ze skutecznej organizacji pracy zespołów oraz z profesjonalnego stylu prowadzenia samych obrad. Zgodnie z regulacjami ustawowymi działania organizacyjne były przygotowywane przez odpowiedni urząd publiczny, a bezpośrednio przez wydzieloną w nim komórkę organizacyjną obsługująca konkretną radę (biuro rady). Ale były także znacząco uzupełnianie przez interesariuszy, którzy również prezentowali profesjonalne postawy oraz ponadprzeciętne (na tle innych województw) zaangażowanie.

Co więcej, w świetle autorskich porównawczych badań ${ }^{33}$ powiązań sieciowych (policy networks) małopolska sieć dialogowa wykazywała się największa w kraju gęstością (policy network density) i nosiła wyraźne cechy tzw. koalicji wsparcia (advocacy coalition), w obrębie której zaznaczał się intensywny przepływ zasobów niedostępnych władzom publicznym w zwykłych warunkach. Zasoby te ułatwiały kompleksowe rozwiąywanie regionalnych oraz lokalnych problemów publicznych i przyczyniały się do rozwoju więzi pomostowych (bridging). W wyniku wcześniej przeprowadzonych badań ustalono, że w Małopolsce więzi o charakterze pomostowym rozwijały się pomiędzy różnymi aktorami, środowiskami i wspólnotami, a zarazem w kontekście korzyści lokowanych w pomyślności regionalnych i lokalnych spraw publicznych. Można powiedzieć, że były to wspólne inwestycje w interes publiczny, które przynosiły partykularne korzyści nie tylko bez szkody dla korzyści zbiorowych, ale przyczyniał się do ich pomnażania. W ten sposób erozji ulegały zarazem powiązania bastionowe (bonding). Utrzymanie tego efektu, a nawet wzmocnienie może przyczyniać się do konsolidowania deliberatywnych postaw, upowszechniania deliberatywnych momentów, a w efekcie do wyłaniania się form lokalnych oraz regionalnej formy systemu deliberatywnego.

${ }^{33}$ Sroka, Błaszczyk (2006): 77-90. 


\section{PROPOZYCJA ANALIZY REGIONALNEGO ODDZIAŁYWANIA OŚMIU PRZEREDAGOWANYCH ZASAD ZARZĄDZANIA ŚRODOWISKAMI WSPÓLNOTOWYMI}

W analizie sieciowania autorzy postulują uwzględnić przepływ poszczególnych rodzajów wsparcia, w których uwidoczniają się takie elementy (zasoby), jak: czynnik dostępu (gate keepers ${ }^{34}$ ), ułatwienia materialne i finansowe, zasoby merytoryczne i informacyjne, zasoby symboliczne, zasoby mobilizacyjne, zasoby afiliacji i koalicji, zasoby kapitału społecznego i zaufania ${ }^{35}$. W związu z powyższym, warto poddać weryfikacji osiem zasad zarządzania zasobami środowiskami wspólnotowymi i gospodarki, autorstwa Elinor Ostrom. Rozważania te pozwolą zorientować się, w jakiej mierze oraz ewentualnie, które z nich, sa obecne w procesach koordynacji obu wskazywanych jako przykład rad zarówno w sposób celowy, jak i odruchowy.

W pierwszym przypadku (celowym), gdy pozytywnie zostanie zweryfikowany fakt świadomego i celowego stosowania (poszczególnych lub wszystkich) zasad zarządzania wspólnota, będzie można dalej argumentować na rzecz tezy o wysokiej jakości przywództwa i zaawansowanych kwalifikacjach menadżerskich w analizowanych radach, w których - co prawda w nieco odgórny, ale zarazem przemyślany sposób - liderzy prowadzą deliberatywne wspólnoty ku optymalnym formom zarządzania. Postępujac tak, liderzy przyczyniają się do generowania prodeliberacyjnych zmian w obrębie regionalnych i lokalnych matryc kulturowych. Matryc odpowiedzialnych za indywidualne, grupowe i organizacyjne postawy oraz działania zorientowane na dobro publiczne. W drugim zaś przypadku (odruchowym), gdyby jednak okazało się, że część lub (co tym bardziej wątpliwe) wszystkie zasady zarządzania środowiskami wspólnotowymi stosowane sa w sposób niewymuszony i odruchowy, wówczas przemawiałoby to za teza, że część ze wspomnianych matryc uległa już pozytywnym zmianom. A stało się to dzięki praktykowaniu regionalnych form dialogu lub też dlatego, że wcześniej były one już w badanym regionie kulturowo uzgodnione (tj. zinternalizowane) i jedynie ujawniają się teraz, przy okazji dialogu w postaci działań odruchowych, tzn. zgodnych z kulturową matrycą. Zakłada się, że w badawczej praktyce będzie możliwe odnalezienie raczej jakiejś wypadkowej wariantów pierwszego i drugiego.

W skład wspomnianych ośmiu zasad zarządzania środowiskami wspólnotowymi (principles for managing a commons ${ }^{36}$ ) autorstwa Ostrom wchodzą wymienione dalej elementy, których obecność w zarządzaniu dialogiem regionalnym może

34 Zob. Kaase (1999).

35 Por. Copeland, Taylor (2009); Noworól (2014); Ostrom (1999), (2013); Hess, Ostrom (2001); Ostrom, Gardner, Walker (2006); Sroka (2002): 264-275.

${ }^{36}$ Ostrom zaproponowała, że w procesie dysponowania wspólnymi zasobami należy: (1) jasno definiować granice dobra wspólnego, (2) stworzyć zasady regulujące korzystanie z dobra wspólnego dopasowane do lokalnych warunków, (3) umożliwić funkcjonowanie możliwie demokratycznych procesów zarządzania dobrem, (4) kontrolować dotrzymywanie wspólnotowych reguł przez członków wspólnoty albo przez zewnętrznych aktorów odpowiedzialnych wobec wspólnoty, (5) stopniować sankcje w razie złamania zasad wspólnotowych w sytuacjach kryzysowych, (6) tworzyć efektywne i niekosztowne mechanizmy rozwiązywania konfliktów, (7) dążyć do akceptacji in- 
zostać z powodzeniem przetestowana podczas badań empirycznych. Poszczególne zasady lekko przeredagowano, dostosowując je do polskich uwarunkowań:

1. Jasne definiowanie granic środowiska wspólnotowego - w tekście używa się sformułowania ,środowisko wspólnotowe”, a nie jak w oryginale Ostrom po prostu „wspólnota” - aby uwypuklić znaczenie sieci, ponieważ dla autorów istotne jest to, w jaki sposób lokalizuje się zasięg oddziaływań sieciowych, czyli jak daleko sięga moc sprawcza deliberacji prowadzonych w radach. Takie postrzeganie jest bardziej oczywiste w skonsolidowanych demokracjach, a w Polsce sposób postrzegania sieci oraz granic oddziaływań wspólnoty jest wciąż jeszcze problemem do zbadania.

2. Dopasowywanie zasad wielopasmowego zarządzania zasobami do lokalnych potrzeb, uwarunkowań oraz charakteru powiązań sieciowych oraz bieżące radzenie sobie z konfliktami powstajacymi na tym tle.

3. Stwarzanie warunków do tego, aby aktorzy, których dotyczą reguły, mogli także uczestniczyć w modyfikowaniu tych reguł - takie rozstrzygnięcia będą skuteczne, o ile uczestnicy potraktuja je jako uzasadnione, uczciwe i pozwalające osiagnąć założone cele.

4. Dokładanie starań, aby ustalone w dialogu rozstrzygnięcia były przestrzegane przez zewnętrzne podmioty publiczne i niepubliczne.

5. Rozwijanie systemu monitorowania i ewaluacji problemów publicznych będących w polu zainteresowania rad dialogu, a także postaw i działań aktorów zaangażowanych $\mathrm{w}$ te problemy oraz bezpośrednio zainteresowanych ich rozwiązywaniem.

6. Tworzenie skutecznych narzędzi wpływu, które stanowić będą środowiskowo-sieciowy ekwiwalent stopniowalnych sankcji wobec aktorów naruszających (głównie nieformalne) zasady związane wzajemnościa, lojalnościa, zaufaniem itd.

7. Wypracowanie własnych, skutecznych sposobów rozwiązywania sporów, które mają zastosowanie na przykład w tzw. misjach dobrej woli, które przewidziano w cytowanych polskich rozwiąaniach ustawowych.

8. Budowanie klimatu odpowiedzialności za zarządzanie wspólnymi zasobami i skuteczne jego zagnieżdżanie na możliwie wszystkich poziomach oraz polach regionalnego systemu deliberatywnego.

Zakłada się, że zbadanie, czy, jakie, a także w jakim stopniu wymienione zasady są stosowane w radach w sposób celowy bądź odruchowy, pozwoli również zbliżyć się do odpowiedzi na pytanie, jakiego rodzaju sieci przeważają w regionalnym dialogu rozwijanym $\mathrm{w}$ kontekście funkcjonowania przedmiotowych rad. W wariancie optymalnym uda się przedstawić kontinuum regionalnych układów sieciowych ujawniajacych się przy okazji prac dwóch analizowanych instytucji dialogowych. W pełnym spektrum tego kontinuum mogłyby zostać uwzględnione następujące układy powiązań (oraz ich hybrydy) ${ }^{37}$ :

stytucji wspólnego zarządzania dobrem przez instytucje zewnętrzne, (8) w przypadku większych dóbr wspólnych powoływać instytucje wielopoziomowe.

${ }^{37}$ Por. Sroka, Błaszczyk (2006); Hindmoor (1998); Marsh, Rhodes (1992); Rhodes (1996); Sroka, Herbut, Sula (2004). 
Schemat

Kontinuum układów sieciowych w polityce publicznej (policy networks)

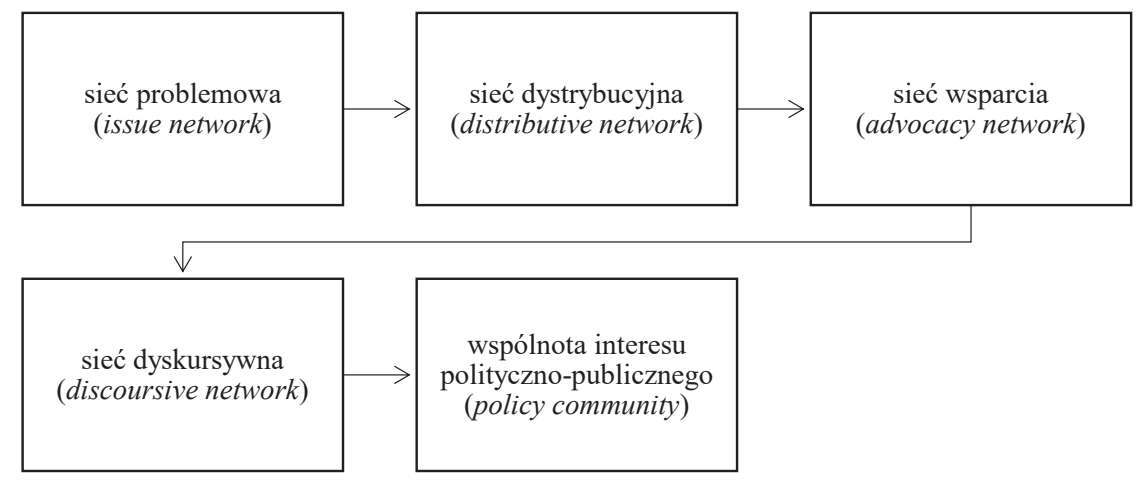

Źródło: opracowanie własne na podstawie Sroka (2004): 115-173.

\section{MOŻLIWE WARIANTY REALNYCH WCIELEŃ I DEFORMACJI ZAŁOŻEŃ MODELOWYCH W POLSKICH REGIONACH}

Zakłada się trzy hipotetyczne warianty końcowych odpowiedzi na pytanie o ewentualność wyłaniania się konsensualnego modelu dialogu regionalnego. Zostały one przez autorów ujęte w postaci trzech głównych założeń. Założenie pierwsze brzmi, że obie rady nie mają się czego od siebie uczyć, gdyż aktualnie działają w: (a) podobnie niewydolny i daleki od deliberacji sposób albo (b) sukcesy oraz przykłady lepszego funkcjonowania widoczne są jedynie tam, gdzie zarysowało się oddziaływanie skutecznego przywództwa jednej z zaangażowanych w dialog stron. Niedomagania obu rad zakorzenione sa w podobnego rodzaju uwarunkowaniach instytucjonalno-systemowych, których blokujacej siły oddziaływania nie da się osłabić drogą organizacyjnego uczenia się, gdyż „nie ma się komu oraz nie ma się czego uczyć”. Założenie drugie natomiast wiąże się z przyjęciem, że jedna z badanych rad funkcjonuje skuteczniej, dynamiczniej oraz w bardziej zróżnicowany sposób, a główną tego przyczyna jest jej skład po stronie interesariuszy (organizacji partnerów społecznych oraz organizacji partnerów obywatelskich). Ich aktywność przyczynia się do ożywienia dialogu i (a) skłania władze publiczne do większej aktywności bądź (b) przyczynia się do efektywnego działania Rady. W myśl założenia trzeciego obie rady działaja w podobnie skuteczny i sprzyjający rozwojowi deliberacji sposób, a wynika to, z jednej strony (a) ze składu interesariuszy, a z drugiej (b) z zaangażowania przedstawicieli władz publicznych.

Z weryfikacji powyższych założeń mogą wynikać dwie generalne konstatacje: negatywna lub pozytywna. Każda z nich w odmienny sposób wpłynie na kształt ostatecznych wniosków korygujących założenia modelowe oraz inaczej ukierunkuje rekomendacje. Przewidywana konstatacja negatywna byłaby bliska stwierdzeniu, że dialog regionalny w Polsce stanowi hybrydę etatyzmu, 
przebrzmiałych wzorców (neo)korporatystycznych ${ }^{38}$ oraz oddziaływań ukrytych grup interesu i - jako taki - jest odległy od współczesnych modeli oraz praktyk deliberacji i rządzenia wielopasmowego. Przewidywana konstatacja pozytywna wynikałaby z potwierdzenia zarówno faktu pojawiania się deliberatywnych postaw, jak i deliberatywnych momentów w obu radach i nawiązywałaby do koncepcji regionu uczącego się. Potencjalnie obie rady mogłyby wzajemnie korzystać na wymianie dobrych praktyk oraz na wprowadzaniu formalno-instytucjonalnych, wzajemnie zapożyczonych korekt ${ }^{39}$. Wyniki analizy mają więc konkretne znaczenie systemowe.

Proponowany model zakotwiczony jest w obszarach charakterystycznych dla: badań nad kulturowo-instytucjonalnymi uwarunkowaniami polityki publicznej i zarządzania publicznego podporządkowanego zasadom rządzenia wielopasmowego ${ }^{40}$, dialogiem i deliberacja, analiz grup interesu, analiz układów sieciowych, a także badań nad samorządem terytorialnym i nieterytorialnym, z niezbędnymi elementami analizy prawnej ${ }^{41}$. W studium przypadku Małopolskiej WRDS składowe odpowiedzi na pytanie o występowanie elementów konsensualnego i uniwersalnego w skali kraju modelu dialogu regionalnego odnosić się powinny do pytań dotyczących dialogowo-społecznej, ustawowej regulacji: (1) w jakiej mierze nowa regulacja zmienia istniejacy dotychczas (tj. od 2001 r.) stan rzeczy w zakresie redukcji „deficytu demokracji” w polskim systemie reprezentacji interesów, nie tylko na jego poziomie regionalnym choć zarazem głównie na nim? (2) Jakie sa formalne oraz realne uwarunkowania pozycji partnerów społecznych, strony rządowej oraz strony samorządowej w polskich regionach? (3) Czy w związku z nową regulacją można mówić o redukcji etatyzmu i wzmocnieniu korporatyzmu w polskim systemie politycznym? (4) Czy oraz w jakim zakresie dostęp do dialogu regionalnego maja niereprezentatywne organizacje partnerów społecznych, inne organizacje trzeciego sektora oraz nieformalne grupy i wspólnoty społeczne? (5) Czy strukturalno-organizacyjny kształt poszczególnych WRDS dostosowany jest do urealniania ich autonomiczności, czy też stanowi efekt zachowawczego powielania wzorców oraz praktyk centralnych?

Z kolei w odniesieniu do WRDPP wielu uczestników dialogu obywatelskiego samorządowców oraz działaczy pozarządowych dostrzega problem systemowy, który wynika niejako z samych przepisów ustawy o działalności pożytku publicznego i o wolontariacie. Problem ten był również przedmiotem wcześniejszych badań autorów ${ }^{42}$. Polega on na zbyt szerokim i w efekcie nie dość jasnym określeniu ich kompetencji, zarówno na poziomie kraju, województwa, powiatu, jak i gminy. Wydaje się, że rady działalności pożytku publicznego powinny mieć mocne i konkretne uprawnienia oraz kompetencje odnoszące się do holistycznego cyklu ich rocznej aktywności, związanego m.in. z przygotowywaniem i rekomendowaniem organowi wykonawczemu projektu zarządzenia

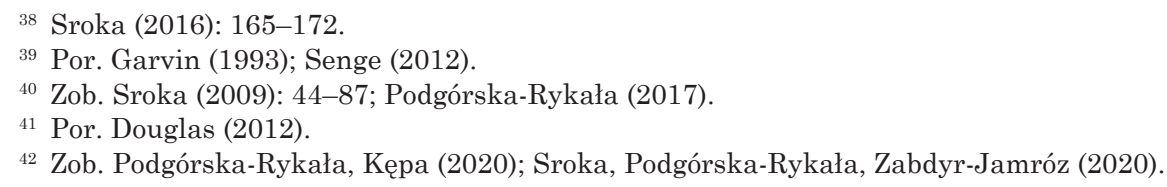


w sprawie przygotowania rocznego programu współpracy JST z NGO; udziałem w pracach nad tym programem oraz w konsultacjach jego zapisów z organizacjami; udziałem w pracach komisji konkursowych oraz monitoringiem realizacji postanowień programu i akceptacją sprawozdania z jego realizacji. Tak domknięty cykl pozwoliłby na zaangażowanie członków rad w kwestie istotne z punktu widzenia organizacji, jednocześnie odciążając je z konieczności swoistego doradzania władzom regionu w innych, mało istotnych kwestiach. Z praktyki wynika bowiem, że w wielu przypadkach sytuacja ta czyni same rady ciałem marginalnym, często wewnętrznie skonfliktowanym lub bezrefleksyjnie opiniujaccym, a załatwiającym jedynie interesy poszczególnych jej członków. Zarazem szerzej nieznanym w środowisku regionalnego trzeciego sektora. Zatem WRDPP powinna mieć zaostrzone kompetencje w zakresie współpracy, a ograniczone w odniesieniu do innych kwestii - tak brzmi kolejna wstępna rekomendacja, którą zweryfikują dalsze badania. Postuluje się, iż ważną kompetencją WRDPP powinno być również stanie na straży jakości oraz poziomu dialogu pomiędzy samorządem a organizacjami w całym regionie - zatem również w gminach i powiatach. Zadanie to mogłoby polegać między innymi na wydawaniu opinii o tym, czy konkretny program został odpowiednio z organizacjami przygotowany i skonsultowany. Kontynuujac ten watek, można dalej postulować, że WRDPP nie powinna przy tym zabierać głosu w odniesieniu do części merytorycznej konkretnego programu, który by opiniowała (np. gminnego programu wspierania osób niepełnosprawnych). Nie powinna tego robić, gdyż pozostawałoby to w kompetencji odpowiedniej, gminnej instytucji dialogowej (tj. gminnej rady działalności pożytku publicznego). Stawia się tu jednak postulat, że WRDPP powinna mocno angażować się w zabezpieczenie prawidłowości proceduralnych oraz jakości takiego gminnego programu. Ważną kwestią w tym kontekście jest fakt, że z uwagi na aktualnie obowiąujący sposób powoływania rad działalności pożytku publicznego nierzadko bywaja one mylone ze swoistą reprezentacją trzeciego sektora, której nota bene nie ma ani w regionie, ani w gminach, powiatach, ani też na poziomie ogólnokrajowym.

Dobra praktyka, która mogłaby przyczynić się do rozwiązania pojawiających się w związku z nieścisłościami dylematów, jest powoływanie w niektórych jednostkach samorządu terytorialnego tzw. komisji dialogu obywatelskiego. Sa to gremia inicjatywno-doradcze, tworzone przez organizacje pozarzadowe, do których zaprasza się także przedstawicieli komórek organizacyjnych danego urzędu. Ustawa o działalności pożytku publicznego i o wolontariacie, oprócz rad działalności pożytku publicznego, wskazuje na możliwość realizacji współpracy między organizacjami pozarządowymi a organami administracji publicznej dzięki tworzeniu takich właśnie wspólnych zespołów o charakterze doradczym i inicjatywnym (art. 5.1 pkt 5 u.d.p.p.w.).

Przetestowanie powyższych założeń i znalezienie odpowiedzi na postawione pytania będzie możliwe dzięki badaniom empirycznym, w trakcie których będzie można zweryfikować natężenie siły słabych więzi w tych małopolskich powiązaniach sieciowych, które ujawniają się przy okazji funkcjonowania obu rad dialogowych. Na podstawie analiz dokumentacji oraz dzięki wywia- 
dom pogłębionym zbadane mogą zostać sieciowe przepływy różnych rodzajów wsparcia pomiędzy uczestnikami dialogu, tj. pomiędzy instytucjami publicznymi i organizacjami, których reprezentuja poszczególni uczestnicy dialogu. Badaniu poddane może zostać również to, czy i w jakim ewentualnie zakresie transfery tak rozumianych zasobów sprzyjaja kreowaniu nowych sieciowych powiązań organizacyjnych i personalnych. Powiązań zarówno pomiędzy uczestnikami dialogu, jak i w szerszym kontekście - obejmujących lokalne środowiska oraz aktorów, organizacje i instytucje publiczne niebędące formalnymi uczestnikami obu rad. Dzięki cząstkowym analizom sieciowych transferów wsparcia będzie można udzielić odpowiedzi na pytanie, czy oraz w jakim zakresie dochodzi do sieciowania pomiędzy Małopolską WRDS oraz Małopolską WRDPP.

\section{SYSTEMOWE ZNACZENIE MODELU}

Tak przedstawiająca się realizacja założeń badawczych może mieć istotne znaczenie systemowe, szczególnie w wymiarze makrosystemowym, gdyż pozwoli na wyodrębnienie istotnych elementów odpowiedzi o stan demokracji w Polsce, a ujmując rzecz dokładniej: umożliwi zweryfikowanie, czy decentralizacja i współdecydowanie to rzeczywiste czy jedynie pozorne składniki rodzimego wcielenia modelu poliarchii Roberta Dahla ${ }^{43}$. Po drugie zaś pozwoli na zweryfikowanie skuteczności obowiązujących rozwiązań formalnoprawnych, skutkujacych określonymi procedurami oraz formami organizacyjnymi obu regionalnych rad.

Zdaniem autorów wśród powodów, które skłaniaja do kontynuowania badań nad polskim dialogiem regionalnym, należy wymienić między innymi potrzebę weryfikacji zasadności oraz skuteczności modyfikacji systemowej wprowadzonej wraz z wejściem w życie ustawy z 24 lipca 2015 r. o Radzie Dialogu Społecznego i innych instytucjach dialogu społecznego. Warto przy tym zaznaczyć, że początek formalnego funkcjonowania regionalnych instytucji dialogu społecznego w Polsce datowany jest na rok 1994, a ustawowo $-2002^{44}$. Weryfikacji należy także poddać rozwiązania cytowanej ustawy z 24 kwietnia 2003 r. o działalności pożytku publicznego i o wolontariacie.

\section{ZAKOŃCZENIE}

$\mathrm{W}$ prezentowanej propozycji modelowej najistotniejsze pytanie dotyczy tego, czy w ogóle oraz ewentualnie w jakim stopniu podlegają wzajemnej wymianie: regionalne doświadczenia dialogowe, sieci współpracy i inne istotne

${ }^{43}$ Dahl (2012).

${ }^{44}$ Uchwała Rady Ministrów nr 7/94 z 15 lutego 1994 r. o powołaniu Trójstronnej Komisji ds. Społecznych i Gospodarczych; ustawa z 6 lipca 2001 r. o Trójstronnej Komisji ds. Społeczno-Gospodarczych i wojewódzkich komisjach dialogu społecznego, Dz. U. 2001, Nr 100, poz. 1080. 
zasoby, które są wypracowywane w związku z działalnością przedmiotowych rad. Pozytywne zweryfikowanie tego założenia świadczyć będzie o większym prawdopodobieństwie ewolucji rozpatrywanego przypadku w kierunku regionu uczącego się. Natomiast weryfikacja negatywna stanowić będzie argument na rzecz tezy, że w polskich regionach dominuja procesy, mechanizmy i zjawiska bardziej charakterystyczne dla tzw. rozwoju zależnego, a nie innowacyjnej ścieżki rozwojowej.

Rozważania te nawiązują do teorii zależności od ścieżki rozwojowej (path dependency ${ }^{45}$ ), a także znanej tezy Roberta Mertona mówiącej o tzw. samospełniającym się proroctwie, która głosi, iż jeśli ludzie definiują sytuacje jako rzeczywiste, to stają się one rzeczywiste ${ }^{46}$. W dialogu regionalnym liczy się ogólny klimat rozmów i kooperacji, który przesądza o tym, czy towarzyszące mu stany percepcji społecznej i publicznej rzeczywistości sprzyjają otwartemu i innowacyjnemu sieciowaniu o charakterze pomostowym (bridging) oraz wzajemnemu uczeniu się deliberacji, czy może raczej nadal sprzyjają wzmacnianiu „bastionowych” więzi wiążących (bonding), służących selekcjonowaniu poszczególnych środowisk, instytucji i rozwiązań, które jedynie formalnie noszą znamiona deliberacji.

Zdaniem autorów aktywność rad o charakterze dialogowym stanowi istotny element - zarówno w regionie, jak i w kraju - kształtowania się zrębów dialogowego zarządzania środowiskami wspólnotowymi, co z kolei jest jednym z kluczowych składników nowoczesnego rządzenia wielopasmowego. Możliwość dokładnej weryfikacji przyniosą badania terenowe.

Althemeyer, B. (1996). The Authoritarian Specter. Cambridge.

Arrow, K.J. (1951). Social Choice and Individual Values. New York.

Chambers, S. (1996). Reasonable Democracy: Jürgen Habermas and the Politics of Discourse. Ithaca-New York.

Baron-Cohen, S. (2014). Teoria zła. O empatii i genezie okrucieństwa. Tłum. A. Nowak. Sopot.

Black, D. (1948). On the Rationale of Group Decision Making. Journal of Political Economy 56: $23-34$.

Cisek-Lachowicz, M., Kichewko, K. (2018). Dialog obywatelski w praktyce. Studia z Polityki Publicznej 2(18): 59-72.

Copeland, B.R., Taylor, M.S. (2009). Trade, tragedy, and the commons. American Economic Review 99(3): 725-49.

Dahl, R. (2000). O demokracji. Tłum. M. Król. Kraków.

Dahl, R. (2012). Demokracja i jej krytycy. Tłum. S. Amsterdamski. Warszawa.

David, P.A. (2000). Path dependence, its critics and the quest for 'historical economics', [w:] P. Garrouste, S. Ioannides (eds.), Evolution and Path Dependence in Economic Ideas: Past and Present. Cheltenham: 15-40.

Douglas, M. (2012). Jak myślą instytucje. Tłum. O. Siara. Warszawa.

Dryzek, J. (2002). Deliberative Democracy and Beyond: Liberals, Critics, Contestations. New York.

Eysenck, H.J. (1954). The Psychology of Politics. London.

Florida, R. (1995). Toward the learning region. Futures 27: 527-536.

Garvin, D.A. (1993). Building a learning organization. Harvard Business Review 71(4):78-91.

${ }^{45}$ David (2000); Pierson (2000).

${ }^{46}$ Merton (2002): 283-424. 
Gibbard, A. (1973). Manipulation of voting schemes: a general result. Econometrica 41: 587-601.

Gittell, R., Vidal, A. (1998). Community Organisations. Building Social Capital as a Development Strategy. Thousand Oaks.

Granovetter, M.S. (1973). The strength of weak ties. American Journal of Sociology 78(6): 13601380.

Hess, C., Ostrom, E. (2001). Artifacts, facilities, and content: information as a common-pool resource. <web.law.duke.edu/pd/papers/ostromhes.pdf>.

Hindmoor, A. (1998). The importance of being trusted: transaction costs and policy network theory. Public Administration 76(1): 25-43.

Kaase, M. (1999). Interpersonal trust: political trust and non-institutional political participation in Western Europe. West European Politics 22(3): 1-23.

Lehner, F. (1987). Interest intermediation, institutional structures and public policy, [w:] H. Keman, H. Paloheimo, P. Whiteley (eds.), Coping with the Economic Crisis: Alternative Responses to Economic Recession in Advanced Industrial Societies. London: 54-82.

Lijphart, A. (2012). Patterns of Democracy: Government Forms \& Performance in Thirty-six Countries. New Haven.

McKelvey, R.D. (1976). Intransivities and multidimensional voting models and some implications for agenda control. Journal of Economic Theory 12(3): 472-482.

Maia, R.C.M., Danila, C., Bargas, J.K.R., Oliveira, V.V., Rossini, P.G.C., Sampaio, R.C. (2017). Authority and Deliberative Moments: Assessing Equality and Inequality in Deeply Divided Groups. Journal of Public Deliberation 13(2), Art. 7.

Mansbridge, J.J, Flaster, K. (2007). The cultural politics of everyday discourse: the case of "male chauvinist”. Critical Sociology 33(4): 627-660.

Mansbridge, J.J., Bohman, J., Chambers, S., Estlund, D., Føllesdal, A., Fung, A., Lafont, Ch., Manin, B., Marti, J.L. (2010). The place of self-interest and the role of power in deliberative democracy. Journal of Political Philosophy 18(1): 64-100.

Marsh, D., Rhodes, R.A.W. (1992). Policy Networks in British Government. Oxford.

Merton, R. (2002). Teoria socjologiczna i struktura społeczna. Tłum. E. Morawska, Warszawa.

Noworól, A. (2014). Zarządzanie rozwojem funkcjonalnych obszarów miejskich w świetle koncepcji Adaptive Governance Elinor Ostrom, [w:] A. Kołomycew, B. Kotarba (red.), Partnerstwa w sferze publicznej. Warszawa: 99-110.

Olson, M. (1971). The Logic of Collective Action: Public Goods and Theory of Groups. CambridgeLondon.

Olson, M. (1982). The Rise and Decline of Nations: Economic Growth, Stagflation and Social Rigidities. New Haven.

Ostrom, E. (1999). Governing the Commons. The Evolution of Institutions for Collective Action. New York.

Ostrom, E. (2013). Dysponowanie wspólnymi zasobami. Tłum. Z. Wiankowska-Ładyka. Warszawa.

Ostrom, E., Gardner, R., Walker, R. (2006). Rules, Games, \& Common-Pool Resources. Ann Arbor.

Owen, D., Smith, G. (2015). Survey article: deliberation, democracy, and the systemic turn. Journal of Political Philosophy 23(2): 213-234.

Parkinson, J. Mansbridge, J. (eds.) (2012). Deliberative Systems. New York.

Pierson, P. (2000). Increasing returns. path dependence and the study of politics. American Political Science Review 94(2): 251-267.

Podgórska-Rykała, J. (2017). Administrowanie, zarządzanie, współrządzenie w administracji publicznej. Różne koncepcje i ich konsekwencje dla obywateli, [w:] M. Gurdek (red.), Zarządzanie jednostkami samorządu terytorialnego w warunkach gospodarki rynkowej. Sosnowiec: $29-40$.

Podgórska-Rykała, J. (2020). Panele obywatelskie jako metoda deliberacji decyzyjnej. Warszawa.

Podgórska-Rykała, J., Kępa, M. (2020). Współpraca międzysektorowa jednostek samorządu terytorialnego z organizacjami pozarządowymi. Kraków.

Rhodes, R.A.W. (1996). The New Governance: Governing without Government. Political Studies 44: 652-667.

Rhodes, R.A.W. (2008). Policy network analysis, [w:] M. Moran, M. Rein, Martin, R.E. Goodin (eds.), TheOxford Handbook of Public Policy. New York doi:10.1093/oxfordhb/9780199548453.003.0020. 
Rokeach, M. (1960). The Open and Closed Mind. New York.

Sen, A.K. (1978). Collective Choice and Social Welfare, San Francisco.

Senge, P. (2012). Piąta dyscyplina. Teoria i praktyka organizacji uczących się. Tłum. H. Korolewska-Mróz, Warszawa.

Sroka, J. (2000). Europejskie stosunki przemysłowe w perspektywie porównawczej. Wrocław.

Sroka, J. (2002). Zasoby organizacji grup interesu, [w:] B. Rogowska, J. Tomaszewski, K. Dziubka (red.), W kręgu historii i politologii. Wrocław: 264-275.

Sroka, J. (2004). Polityka organizacji pracodawców i przedsiębiorców. Wrocław.

Sroka, J. (red.) (2008). Wybrane instytucje demokracji partycypacyjnej w polskim systemie politycznym. Warszawa.

Sroka, J. (2009). Deliberacja i rządzenie wielopasmowe. Wrocław.

Sroka, J. (2016). Korporatyzm - inspiracje ideowe, cechy wzorca instytucjonalnego, polityka publiczna, [w:] M. Marczewska-Rytko, W. Ziętara (red.), Ideologie, doktryny, ruchy społeczne i polityczne. Wybrane problemy. Lublin: 165-172.

Sroka, J., Błaszczyk, M. (red.) (2006). Sieci czy struktury? Dialog społeczny na poziomie regionalnym. Warszawa.

Sroka, J., Podgórska-Rykała, J. (2020a). Deliberacyjne metody współdecydowania i niedeliberacyjne metody zasięgania opinii mieszkańców: ujęcie praktyczne. Samorząd Terytorialny 11: 8-18.

Sroka, J., Podgórska-Rykała, J. (2020b). Deliberacja jako możliwa metoda współdecydowania w jednostkach samorządu terytorialnego. Ujęcie teoretyczno-modelowe. Samorząd Terytorialny 7/8: 54-65.

Sroka, J., Podgórska-Rykała, J. (2020c). Intermediacja interesów, czyli o roli indywidualnych wkładów w grupowych działaniach: kiedy niezorientowana publicznie grupa interesu staje się zorientowanym publicznie interesariuszem? [w:] T. Grabińska, Z. Kuźniar (red.), Bezpieczeństwo personalne a bezpieczeństwo strukturalne. Tom 8: Struktura warstwowa bezpieczeństwa. Wrocław: 61-78.

Sroka, J., Herbut, R., Sula, P. (2004). Dialog społeczny na poziomie regionalnym. Raport z badań. Warszawa.

Sroka, J., Podgórska-Rykała, J., Zabdyr-Jamróz, M. (eds.) (2020). Local Governance - Ideas, Concepts, Experiences and Goals for the Future. Kraków.

Steiner, J., Jaramillo, M.C., Mameli, S. (2017). Deliberation Across Deeply Divided Societies. Transformative Moments. Cambridge.

Tomkins, S. (1963). Left and right: a basic dimension of ideology and personality, [w:] R.W. White (ed.), The Study of Lives. New York.

Zabdyr-Jamróz, M. (2019). Wszechstronniczość. Deliberacja o emocjach, interesach własnych i wiedzy eksperckiej w polityce zdrowotnej. Kraków.

\section{THE DETERMINANTS OF THE CONSENSUAL MODEL OF SOCIAL DIALOGUE AND CIVIC DIALOGUE AT THE REGIONAL LEVEL IN POLAND}

\section{Sum mary}

This article focuses on searching for a consensual model of similarities, differences, transfers of practices, and lending networks in regional dialogue, which would be appropriate for Polish realities. These considerations are made within the framework of an analysis of two institutionalized varieties of dialogue: social and civil dialogue at the level of voivodship. Elements of a model answer to the issues addressed by the authors are constructed with reference to the Malopolska region, which was selected due to the results of nationwide research - conducted earlier by one of the authors - indicating that this region has a clear potential which favours the development of dialogue institutions. The authors use the categories indicated, taking into account the tool of public deliberation. Following theorists and practitioners, they consider deliberation as one of the most optimal dialogical (pre)decision-making paths, since it leads to effective and acceptable decisions and enables the optimal, fair and transparent public management of environmental resources. It is assumed that the mutual learning of new ways of doing things by specific insti- 
tutions engaged in social and civil dialogue enables the correction of already established nondialogue elements in the future. It is also assumed that, according to the concept of so-called learning regions, other regions are able to learn dialogue from one region. The authors use the methodology of the social sciences, and in particular they reach for proposals of public policy studies, which they supplement with elements of formal and institutional analysis. The method used for this purpose is a comparative analysis of social and civil dialogue in Polish regions, along with the use of legal analysis and borrowings from case studies carried out in earlier research.

Keywords: social dialogue; civil dialogue; deliberation; region; Lesser Poland Voivodeship (województwo małopolskie) 